\title{
Kesiapsiagaan Rumah Tangga Terhadap Bencana Banjir Di Kelurahan Gunung Lingai Kecamatan Sungai Pinang Kota Samarinda
}

\author{
Santi Yatnikasari ${ }^{1}$, Muhammad Noor Asnan ${ }^{2}$, Fitriyati Agustina ${ }^{3}$ \\ Fakultas Sains dan Teknologi, Universitas Muhammadiyah Kalimantan Timur ${ }^{1,2,3}$ \\ Email: sy998@umkt.ac.id ${ }^{1}$, mna985@umkt.ac.id ${ }^{2}$, fa444@umkt.ac.id ${ }^{3}$ \\ DOI: http://dx.doi.org/10.31869/rtj.v4i1.2208
}

\begin{abstract}
Kesiapsiagaan adalah proses manajemen bencana, yang merupakan salah satu elemen penting dari kegiatan pencegahan pengurangan resiko bencana. Banyaknya korban dan kerugian besar pada bencana banjir menggambarkan kurangnya pengetahuan yang dimiliki seseorang dan sikap yang dilakukan sebagai upaya anstisipasi dan pengurangan resiko bencana. Tujuan penelitian ini adalah untuk mengetahui pengaruh pengetahuan dan sikap tentang resiko bencana banjir terhadap kesiapsiagaan kepala keluarga dalam menghadapi bencana banjir di kelurahan Gunung Lingai kecamatan Sungai Pinang kota Samarinda. Populasi dalam penelitian ini adalah perwakilan rumah tangga yang berada didaerah rawan banjir. Teknik pengambilan sampel menggunakan simple random sampling, dan teknik pengambilan data adalah dengan pengisian kuesioner, wawancara dan observasi. Penelitian ini menggunakan pendekatan deskriptif kuantitatif dan kualitatif. Teori yang digunakan mengacu pada kesiapsiagaan dari LIPI-UNESCO (2006) yang terdiri dari empat parameter yakni pengetahuan dan sikap, sistem peringatan bencana, rencana tanggap darurat dan mobilisasi sumber daya. Penelitian ini diharapkan dapat menambah wawasan kepala keluarga yang merupakan bagian dari masyarakat sehingga dapat meningkatkan kesadaran akan pentingnya pengetahuan dan kesiapsiagaan tentang bencana banjir. Kedepannya penelitian ini juga dapat digunakan oleh pemerintah kota Samarinda dan memberikan pandangan bagi instansi yang berkepentingan dalam upaya pengembangan pendidikan bencana terutama dalam meningkatkan pengetahuan dan kesiapsiagaan masyarakat dalam menghadapi banjir.
\end{abstract}

Keywords: Kesiapsiagaan, Banjir, Gunung Lingai

\section{PENDAHULUAN}

Kesiapsiagaan terhadap bencana merupakan rangkaian tindakan, persiapan serta kegiatan yang dilakukan baik ditatanan individu, kelompok atau masyarakat dalam menghadapi dan mengantisipasi setiap ancaman bencana yang mengancam kelansungan hidup melalui upaya pengorganisasian yang terencana, tepat guna dan berdaya guna (Undang-undang Nomor 24, 2007). Kesiapsiagaan merupakan salahsatu mekanisme penanggulangan bencana serta sebagai upaya untuk antisipasi dan pengurangan akbiat terjadinya resiko bencana. Kegiatan yang dilakukan untuk peningkatan kesiapsiagaan adalah dengan cara peningkatan pengetahuan dan sikap yang dilakukan masyarakat.

Pengalaman yang ada membuktikan bahwa kurangnya pengetahuan yang dimiliki, rendahkan sikap untuk melakukan antisipasi resiko terjadinya bencana, perilaku negatif untuk pencegahan bencana, serta kurangnya kesiapsiagaan dalam menghadapi suatu kondisi bencana memicu untuk terjadinya peningkatan resiko saat bencana terjadi (Bakornas, 2007).

Kesiapsiagaan dalam bencana dapat dikelompokan menjadi empat parameter utama yaitu pengetahuan dan sikap, perencanaan kondisi kedaruratan, sistem peringatan dini dan mobilisasi sumber daya (LIPI-UNESCO, 2006). Empat parameter ini merupakan penentu utama penurunan resiko akibat terjadinya bencana pada suatu wilayah. Penurunan satu parameter dapat berakibat terjadinya peningkatan resiko akibat kejadian bencana.

Bencana adalah rangkaian peristiwa yang mengancam dan mengganggu kehidupan masyarakat baik yang disebabkan oleh faktor alam atau non alam, maupun faktor manusia sehingga mengakibatkan timbulnya korban jiwa, kerusakan lingkungan, kerugian harta benda dan dampak psikologis (Undangundang Nomor 24, 2007). Banjir merupakan bencana alam yang perlu mendapat perhatian, karena mengancam jiwa dan ekonomi masyarakat dan merupakan bencana alam yang ketiga terbesar di dunia yang telah banyak menelan korban jiwa dan kerugian harta benda 
(Aryono, 2011). Banyaknya korban dan kerugian besar pada bencana tersebut menggambarkan kurangnya pemahaman tentang karakterisitik bahaya, sikap atau perilaku yang mengakibatkan penurunan sumber daya alam, kurangnya informasi peringatan dini yang mengakibatkan ketidaksiapan, dan ketidakberdayaan atau ketidakmampuan dalam menghadapi bencana (Bakornas, 2007).

Masyarakat harus berperan serta untuk bersiap sedia menghadapi ancaman banjir dengan persiapan dini, serta pengetahuan yang cukup untuk menghadapi bencana banjir. Kesiapsiagaan dalam menghadapi bencana banjir akan membantu masyarakat dalam membentuk dan merencanakan tindakan apa saja yang perlu dilakukan ketika banjir. Kesuksesan dalam penanganan dan evakuasi/pengungsian ketika banjir sangat bergantung dari kesiapsiagaan masyarakat dan perseorangan itu sendiri. Kualitas terganggunya aspek kehidupan masyarakat sangatlah bergantung kepada besar kecilnya ancaman bencana tersebut, juga dipengaruhi oleh kapasitas masyarakat yang ada serta kerentanan (Daryono, 2010). Adapun tujuan dari penelitian ini adalah untuk mengetahui pengaruh pengetahuan dan sikap terhadap kesiapsiagaan masyarakat dalam menghadapi bencana banjir di kelurahan Gunung Lingai kecamatan Sungai Pinang kota Samarinda.

\section{METODE PENELITIAN}

Penelitian ini merupakan bentuk penelitian studi kasus, dengan mengambil sampel warga perumahan Griya Mukti kelurahan Gunung Lingai kecamatan Sungai Pinang kota Samarinda. Studi kasus adalah penelitian tentang status subjek penelitian yang berkenaan dengan suatu fase spesifik atau khas dari keseluruhan personalitas, dengan subjek penelitian dapat saja individu, kelompok, lembaga, maupun masyarakat (Nazir, 1983).

Sampel adalah bagian dari jumlah dan karakteristik yang dimiliki oleh populasi tersebut (Sugiyono, 2013). Teknik pengambilan sampel dalam penelitian ini menggunakan bantuan tabel penentuan sampel (Isaac dan Michael dalam Sugiyono, 2013). Jumlah sampel yang diperoleh dari tabel penentuan sampel dengan populasi 1.390 kepala keluarga di kelurahan Gunung Lingai adalah 283 kepala keluarga. Dalam banyak kesempatan, kepala keluarga bertindak sebagai perwakilan rumah tangga. Apabila kepala keluarga tidak berada di tempat, maka dapat diwakili oleh anggota keluarga lain yang dianggap mampu memberikan informasi (LIPI-UNECO, 2006).

Teknik pengumpulan data berdasarkan data primer dan data sekunder. Data primer diperoleh melalui observasi dan kuesioner, data sekunder diperoleh melalui tinjauan pustaka dan dokumentasi. Analisis data penelitian adalah dengan menggunakan metode deskriptif campuran (Mixed Method) memadukan pendekatan kualitatif dan kuantitatif. Mixed Method sebuah metodologi yang memberikan petunjuk cara pengumpulan data dan menganalisis data, serta perpaduan pendekatan kualitatif dan kuantitatif melalui beberapa fase proses penelitian (Sugiyono, 2013).

Analisis deskriptif pada penelitian ini menggunakan prosentase dan analisis statistik dengan regresi linier.

\section{Variabel Pengetahuan}

Data yang diperoleh dari hasil tes dan skor angket yang telah diisi oleh responden kemudian dihitung frekuensi jawaban yang benar setiap responden. Selanjutnya dilakukan analisis persentase dengan rumus seperti dikemukakan Sudjana (2001) berikut :

$$
P=\frac{f}{n} \times 100 \%
$$

Klasifikasi presentase yaitu menggunakan tabel 1 Kriteria Pengetahuan berikut :

Tabel 1 Kriteria Tingkat Variabel

\begin{tabular}{ccc}
\hline No & Interval & Kriteria \\
\hline 1 & $25,00-43,7$ & Sangat Rendah \\
2 & $43,76-62,50$ & Rendah \\
3 & $62,51-81,25$ & Tinggi \\
4 & $81,26-100$ & Sangat Tinggi \\
\hline
\end{tabular}

\section{Variabel Sikap}

Analisis persentase untuk variabel ini dihitung berdasrarkan persamaan 1. Selanjutnya diklasifikasikan berdasarkan tabel 2 berikut : 
Tabel 2 Kriteria Sikap

\begin{tabular}{cc}
\hline Interval Persentase (\%) & Kriteria \\
& Persentase \\
\hline $86 \%-100 \%$ & Sangat Baik \\
$71 \%-85 \%$ & Baik \\
$56 \%-70 \%$ & Cukup Baik \\
$41 \%-55 \%$ & Kurang Baik \\
$25 \%-40 \%$ & Tidak Baik \\
\hline
\end{tabular}

Sumber : Analisis Data Penelitian

\section{Variabel Kesiapsiagaan}

Analisis indeks digunakan untuk mengukur tingkat kesiapsiagaan kepala keluarga menghadapi bencana banjir. Indeks tingkat kesiapsiagaan dapat dilihat pada tabel 3.

Tabel 3 Indeks Tingkat Kesiapsiagaan

\begin{tabular}{cc}
\hline Nilai Indeks & Kategori \\
\hline $80 \%-100 \%$ & Sangat Siap \\
$65 \%-79 \%$ & Siap \\
$55 \%-64 \%$ & Hampir Siap \\
$40 \%-54 \%$ & Kurang Siap \\
$<40 \%$ & Belum Siap \\
\hline
\end{tabular}

Sumber : Analisis Data Penelitian

Menurut LIPI-UNESCO (2006) untuk menentukan nilai indeks per parameter, maka digunakan rumus sebagai berikut :

Indeks

$$
=\frac{\text { Jumlah Skor Riil Parameter' }}{\text { Skor 'Maksimum Parameter' }} \times 100
$$

Tabel 4 Bobot parameter kesiapsiagaan

\begin{tabular}{lc}
\hline \multicolumn{1}{c}{ Parameter Kesiapsiagaan } & Bobot \\
\hline Pengetahuan dan Sikap & 45 \\
Rencana Tanggap Darurat & 35 \\
Mobilisasi Sumber Daya & 15 \\
Sistem Peringatan Bencana & 5 \\
\hline Jumlah & 100 \\
\hline \multicolumn{2}{l}{ Sumber : LIPI-UNESCO, 2006 }
\end{tabular}

\section{HASIL DAN PEMBAHASAN}

Secara adminstratif Kelurahan Gunung Lingai berada di Kecamatan Sungai Pinang, Kota Samarinda. Pada gambar 1 menunjukkan peta banjir yang melanda seluruh warga di kelurahan Gunung Lingai.

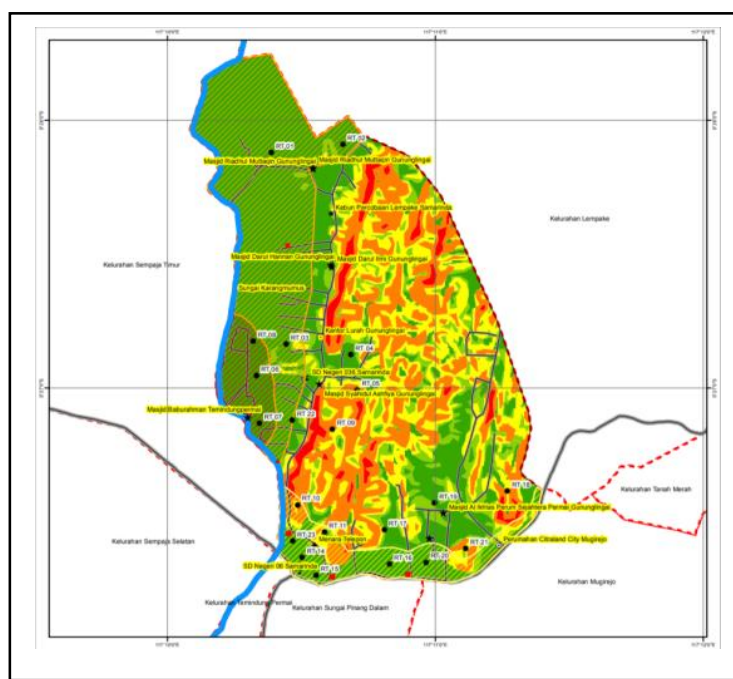

Gambar 1 Peta Banjir Kelurahan Gunung Lingai Kecamatan Sungai Pinang

Berdasarkan data yang diperoleh, Kelurahan Gunung Lingai terdiri dari 21 RT. Dipilihnya warga perumahan Griya Mukti kelurahan Gunung Lingai kecamatan Sungai Pinang kota Samarinda sebagai populasi dalam penelitian ini karena informasi dari BPBD kota Samarinda bahwa di lokasi tersebut merupakan tempat yang mempunyai historis kejadian banjir cukup parah di kota Samarinda. Sejarah mencatat banjir terbesar Samarinda terjadi pada tahun 1998 dan 2008 silam. Kembali terjadi lagi pada bulan Juni tahun 2019, seperti pada gambar 2. Berdasarkan data Badan Penanggulangan Bencana Daerah (BPBD) kota Samarinda, warga korban banjir di Samarinda Kalimantan Timur terdeteksi sebanyak 30.580 jiwa, yakni di Kecamatan Samarinda Utara, Sungai Pinang dan Samarinda Ulu. Jumlah penduduk yang terdampak banjir di perumahan Griya Mukti Kelurahan Gunung Lingai kecamatan Sungai Pinang adalah 4.764 jiwa, 1.390 kepala keluarga. Hal tersebut dijadikan pertimbangan dalam melakukan pemilihan sampel responden yang dapat mewakili populasi yang ada. Berdasarkan informasi dari kelurahan Gunung Lingai melalui wawancara mendalam dengan Lurah Gunung Lingai, diperoleh informasi bahwa wilayah yang sering mengalami banjir terparah adalah perumahan Griya Mukti dengan kedalaman $50-75 \mathrm{~cm}$. Bahkan di RT 6, 7 dan 8, terdiri dari $304 \mathrm{KK}$, ketinggian air antara 80-170 $\mathrm{cm}$ dengan durasi banjir lebih dari 7 hari, ditunjukkan pada gambar 3 yaitu kejadian banjir di kelurahan Gunung Lingai 
Tabel 6 Karakteristik variabel sikap

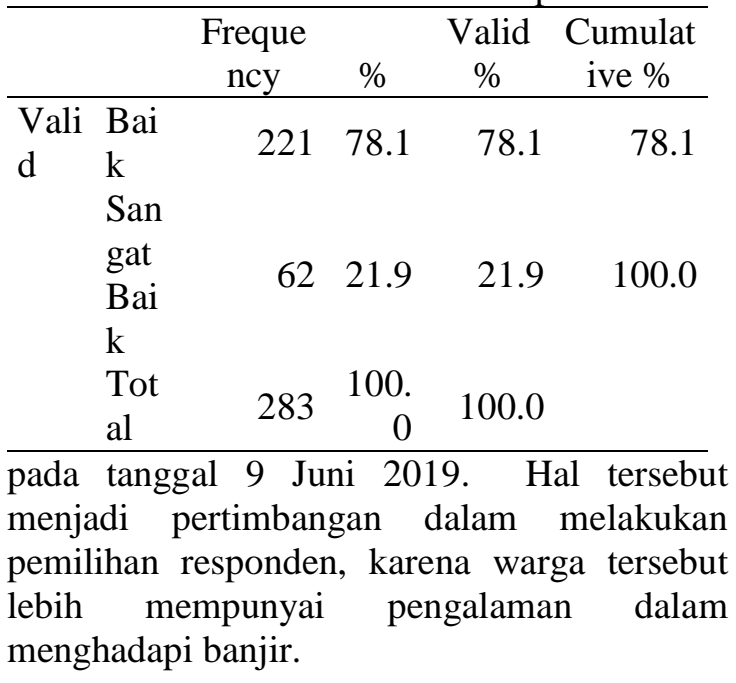

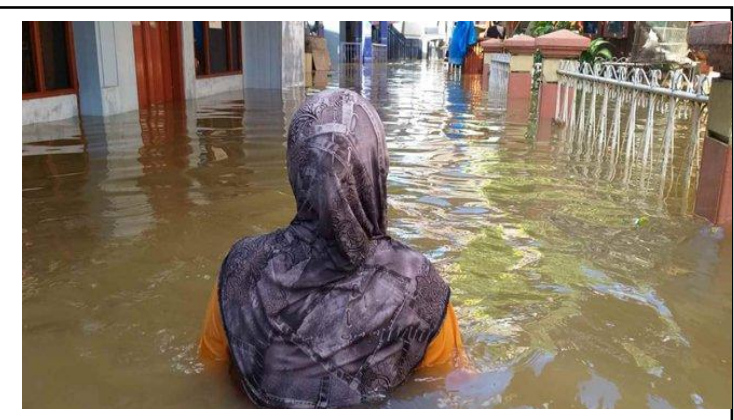

Gambar 2 Kejadian Banjir tanggal 9 Juni 2019 di Kelurahan Gunung Lingai Kecamatan Sungai Pinang

Karakteristik responden berdasarkan variabel pengetahuan ditunjukkan pada tabel berikut:

Tabel 5 Karakterisitik Variabel Pengetahuan

\begin{tabular}{llrrrr}
\hline & & $\begin{array}{c}\text { Freque } \\
\text { ncy }\end{array}$ & \multicolumn{2}{c}{$\begin{array}{c}\text { Valid } \\
\%\end{array}$} & $\begin{array}{c}\text { Cumulat } \\
\text { ive } \\
\%\end{array}$ \\
\hline $\begin{array}{l}\text { Val } \\
\text { id }\end{array}$ & Tinggi & 129 & $\begin{array}{r}45 . \\
6\end{array}$ & 45.6 & 45.6 \\
& Sangat & & 54. & 54.4 & 100.0 \\
& Tinggi & 154 & 4 & & \\
& Total & 283 & 100 & 100.0 & \\
& & & .0 & & \\
\hline
\end{tabular}

Sumber : Hasil Analisis Data

Berdasarkan Tabel 5 pada karakteristik variabel pengetahuan. Responden memiliki kategori pengetahuan tinggi yaitu sebanyak 129 orang $(45,6 \%)$. Sedangkan responden yang memiliki kategori pengetahuan sangat tinggi yaitu sebanyak 154 orang $(54,4 \%)$.
Karakteristik responden berdasarkan variabel sikap ditunjukkan pada tabel 6 berikut:

\section{Sumber : Hasil Analisis Data}

Berdasarkan Tabel 6 pada karakteristik variabel sikap. Mayoritas responden memiliki kategori sikap yang baik yaitu sebanyak 221 orang $(78,1 \%)$. Sedangkan responden yang memiliki kategori sikap yang sangat baik yaitu sebanyak 62 orang $(21,9 \%)$.

Tingkat kesiapsiagaan kepala keluarga dalam mengantisipasi bencana banjir di perumahan Bengkuring kelurahan Sempaja Timur secara umum dapat tercermin dalam bentuk indeks gabungan tiap parameter, yaitu indeks pengetahuan dan sikap, indeks rencana tanggap darurat, indeks mobilisasi sumber daya, dan indeks sistem peringatan bencana. Tingkat kesiapsiagaan kepala keluarga dalam menghadapi banjir ditunjukkan pada tabel 7 .

Tabel 7 Tingkat Kesiapsiagaan Rumah tangga

\begin{tabular}{|c|c|}
\hline $\begin{array}{c}\text { Parameter } \\
\text { Kesiapsiagaan }\end{array}$ & $\begin{array}{l}\text { Tingkat } \\
\text { Kesiap } \\
\text { siagaan }\end{array}$ \\
\hline Pengetahuan dan Sikap & 86,6 \\
\hline $\begin{array}{l}\text { Rencana Tanggap } \\
\text { Darurat }\end{array}$ & 66,5 \\
\hline $\begin{array}{l}\text { Mobilisasi Sumber } \\
\text { Daya }\end{array}$ & $\begin{array}{l}\text { Hampir } \\
\text { Siap }\end{array}$ \\
\hline $\begin{array}{l}\text { Sistem Peringatan } \\
\text { Bencana }\end{array}$ & $\begin{array}{l}\text { Kurang } \\
\text { Siap }\end{array}$ \\
\hline $\begin{array}{l}\text { Tingkat Kesiapsiagaan } \\
\text { Rumah Tangga }\end{array}$ & 65,7 Siap \\
\hline $\begin{array}{l}\text { Sumber : Hasil Analisis } \\
\text { Hasil perhitunga } \\
\text { dilakukan secara umum } \\
\text { indeks gabungan k } \\
\text { keluarga di perumahan } \\
\text { Gunung Lingai dalam } \\
\text { nilai indeks } 65,7 \text {. D } \\
\text { tersebut yang paling t } \\
\text { parameter pengetahuan } \\
\text { mencapai 86,6 yaitu } \\
\text { Parameter yang paling } \\
\text { sistem peringatan benca } \\
\text { 47,5 yaitu dalam kondis } \\
\text { parameter lainnya yait }\end{array}$ & $\begin{array}{l}\text { Data } \\
\text { indeks yang telah } \\
\text { menunjukkan bahwa } \\
\text { siapsiagaan kepala } \\
\text { Bengkuring kelurahan } \\
\text { kategori siap dengan } \\
\text { ri empat parameter } \\
\text { nggi nilainya adalah } \\
\text { lan sikap dengan nilai } \\
\text { dalam kondisi siap. } \\
\text { endah nilainya adalah } \\
\text { a dengan nilai indeks } \\
\text { kurang siap. Dan dua }\end{array}$ \\
\hline
\end{tabular}


daya dengan nilai 62,5 dan sistem peringatan bencana dengan nilai 47,5 dengan kondisi siap dan hampir siap.

Berdasarkan Tabel 7 tingkat kesiapsiagaan rumah tangga dalam menghadapi banjir dapat dilihat pada diagram batang berikut:

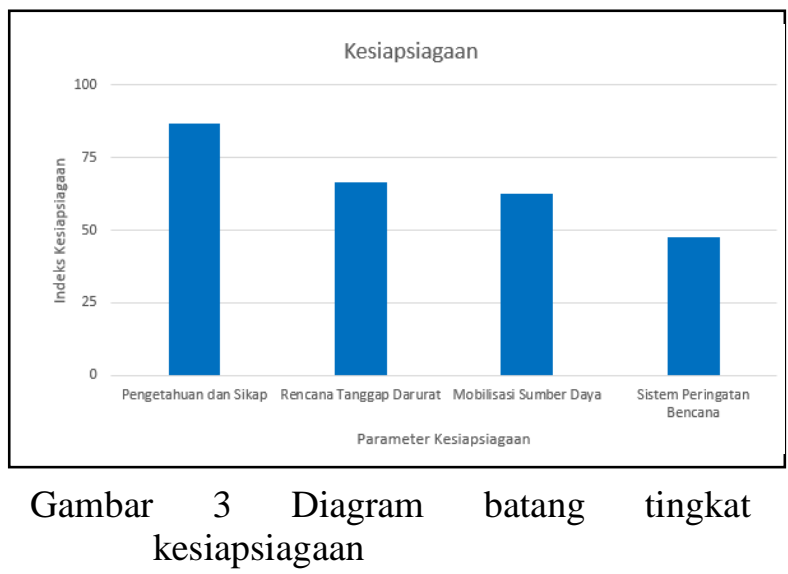

\section{Analisis Regresi Linear Berganda}

Berdasarkan hasil regresi dengan menggunakan program SPSS, maka didapatkan koefisien regresi yang dapat dilihat pada tabel :

Tabel 8 Hasil koefisien regresi linear berganda

\section{Coefficients $^{\mathbf{a}}$}

\begin{tabular}{lcccrr}
\hline & \multicolumn{2}{c}{$\begin{array}{c}\text { Unstandardize } \\
\text { d Coefficients }\end{array}$} & $\begin{array}{c}\text { Standar } \\
\text { dized }\end{array}$ & \\
\cline { 2 - 4 } Model & B & $\begin{array}{c}\text { Std. } \\
\text { Error }\end{array}$ & Beta & $\mathrm{t}$ & Sig. \\
\hline (Constant) & & & & - & .11 \\
& -2.601 & 1.638 & & 1.58 & 3 \\
& & & & 8 & 3 \\
Pengetahua & .411 & .055 & .379 & 7.51 & .00 \\
n & & & & 0 & 0 \\
Sikap & .296 & .043 & .345 & 6.82 & .00 \\
& & & & 9 & 0 \\
\hline
\end{tabular}

a. Dependent Variable: Kesiapsiagaan

Berdasarkan pada tabe 8 maka didapatkan persamaan regresi linier berganda sebagai berikut:

$$
Y=-2,601+0,411 X 1+0,296 X 2+\text { error }
$$

Banjir sebagai salah satu bencana alam adalah peristiwa meluapnya air yang menggenangi permukaan tanah, dengan ketinggian melebihi batas normal (BNPB, 2012). Banjir umumnya terjadi pada saat aliran air melebihi volume air yang yang dapat ditampung dalam sungai, danau, rawa, drainase, tanggul maupun saluran air lainnya pada selang waktu tertentu. Dampak banjir yang bersifat nyata dan terukur secara ekonomi antaralain kerusakan bangunan, infrastruktur, hasil pertanian/peternakan, keterlambatan pasaokan barang-barang kebutuhan pokok dan sebagainya. Sedangkan dampak lainnya adalah timbulnya korban lukaluka maupun korban jiwa serta rusaknya lingkungan. Tingginya curah hujan biasanya menjadi salahsatu faktor penyebab terjadinya banjir di daerah perkotaan. Sama halnya banjir yang terjadi di perumahan Griya Mukti kelurahan Gunung Lingai pada 9 Juni 2019 dan terjadi lagi pada 22 Mei 2020. Curah hujan pada saat itu mencapai 363,1 milimeter yang termasuk dalam kategori sangat tinggi. Oleh karena itu, sangat penting bagi masyarakat untuk mewaspadai banjir dengan meningkatkan kesiapsiagaan rumah tangga dalam mengantisipasi bencana khususnya di daerah rawan banjir.

Pengetahuan yang dimiliki mempengaruhi sikap dan kepedulian masyarakat untuk siap dan siaga dalam mengantisipasi bencana, terutama bagi mereka yang bertempat tinggal di daerah yang rentan terhadap bencana alam (Indawati, 2015). Kepala keluarga yang memiliki kategori pengetahuan tinggi yaitu sebanyak 129 orang $(45,6 \%)$ dan kategori pengetahuan sangat tinggi yaitu sebanyak 154 orang $(54,4 \%)$. Sedangkan kepala keluarga yang memiliki kategori sikap yang baik yaitu sebanyak 221 orang $(78,1 \%)$ dan kategori sikap yang sangat baik yaitu sebanyak 62 orang (21,9\%). Notoatmojo (2007) mengemukakan bahwasanya peningkatan pengetahuan yang dimiliki oleh seorang individu akan memilki korelasi dengan peningkatan perilaku dari individu tersebut. Pengetahuan dan sikap serta kesiapsiagaan yang dimiliki oleh masyarakat khususnya di perumahan Bengkuring kelurahan Sempaja Timur diperoleh dari pengalaman mengalami bencana banjir hampir setiap tahun. Pengalaman tersebut memberikan pengetahuan tentang bencana banjir yang melanda dan akan mempengaruhi sikap dan kepedualian masyarakat untuk siap siaga mengantisipasi banjir. Berdasarkan penelitian yang dilakukan menunjukan bahwa kesiapsiagaan rumah tangga dalam menghadapi banjir dengan nilai 65,7. Hal ini menunjukan bahwa secara umum mereka 
memiliki kemampuan mengenali dan merespon banjir yang berpotensi terjadi di lingkungan tempat tinggal mereka. Kesiapan suatu rumah tangga dalam menghadapi bencana banjir berdampak positif sehingga tidak menyebabkan kerugian besar bagi rumah tangga seperti kerusakan perumahan, perabot rumah tangga, dan lingkungan sekitar.

Dibandingkan dengan parameter kesiapsiagaan bencana yang lain, pengetahuan dan sikap merupakan parameter dengan nilai indeks tertinggi yaitu 86,6. Hal ini menunjukkan bahwa tingkat kesiapsiagaan rumah tangga dalam menghadapi banjir sebagian besar ditentukan oleh pengetahuan dan sikap mereka terkait dengan bencana alam tersebut. Dibuktikan pada persamaan regresi linier berganda : $\mathrm{Y}=-2,601+0,411 \mathrm{X} 1+$ $0,296 \mathrm{X} 2$. Variabel pengetahuan (X1) dan sikap (X2) bernilai positif, artinya pengetahuan dan sikap berpengaruh positif terhadap kesiapsiagaan (Y). Berdasarkan nilai koefisien determinasi $\left(\mathrm{R}^{2}\right)$ pada model yaitu 0,309 . Hal ini menunjukkan bahwa persentase sumbangan pengaruh variabel independen pengetahuan (X1) dan sikap (X2) terhadap variabel kesiapsiagaan (Y) adalah sebesar $30,9 \%$ sedangkan sisanya dipengaruhi faktor lain di luar model regresi tersebut. Berdasarkan hasil uji t menunjukkan bahwa variabel pengetahuan (X1) dan variabel sikap (X2) memberikan pengaruh yang signifikan secara parsial terhadap variabel kesiapsiagaan (Y).

Secara umum warga perumahan Griya Mukti kecamatan Gunung Lingai mengetahui bahwa bencana yang sering terjadi di tempat tinggal mereka adalah banjir yang disebabkan karena karena luapan air sungai dan tingginya curah hujan. Selain itu, mereka juga memahami bahwa tindakan yang harus mereka lakukan apabila terjadi banjir adalah berlindung ke tempat yang lebih aman dan berlari ke tempat pengungsian. Hasil penelitian LIPI-UNESCO (2006) menunjukan bahwa pengetahuan masyarakat tentang bencana akan mempengaruhi sikap dan kepedulian rumah tangga untuk siap dan siaga dalam mengantisipasi terjadinya bencana, sehingga dampak ikutan bencana dapat meminamilisir. Kondisi seperti ini yang kiranya berkontribusi dalam pengurangan dampak bencana banjir di perumahan Griya Mukti kecamatan Gunung Lingai.
Kesiapsiagaan rumah tangga di perumahan Griya Mukti kecamatan Gunung Lingai juga dipengaruhi oleh rencana tanggap darurat dengan nilai indeks 66,5. Rencana tanggap darurat menjadi bagian yang penting dalam proses kesiapsiagaan, terutama yang terkait dengan evakuasi, penyelamatan, agar korban bencana dapat diminimalkan (Firmansyah, 2014). Kepala keluarga mengetahui apa yang harus dilakukan untuk menyelamatkan diri dari banjir seperti menambah pengetahuan tentang banjir, adanya kesepakatan tempat pengungsian/evakuasi, mengetahui tempat menyelamatkan diri pada saat banjir terjadi, dan ada kotak obat. Hal ini mencerminkan bahwa partisipasi kepala keluarga maupun pemerintah dalam hal ini kelurahan Gunung Lingai terbilang aktif dalam menyusun perencanaan tanggap darurat yang meliputi aspek evakuasi, pertolongan dan penyelamatan. Terdapat tenaga sukarela lokal yang tergabung dalam kelompok Siaga Bencana Gunung Lingai. Tinggi rendahnya nilai indeks rencana tanggap darurat juga dipengaruhi oleh pengalaman masyarakat. Masyarakat di perumahan Griya Mukti kecamatan Gunung Lingai sudah sering mengalami banjir sebab wilayah yang mereka huni memiliki riwayat sebagai daerah rawan banjir. Fakta dilapangan juga mendukung hal tersebut sebab apabila musim penghujan tiba dengan intensitas dan curah hujan yang tinggi, maka daerah ini akan mengalami banjir. Apabila banjir terjadi, pengalaman mereka berkontribusi dalam pelaksanaan rencana tanggap darurat keluarga mereka. Hal ini sejalan dengan penelitian Sagala (2014) di kabupaten Bandung yang menunjukkan bahwa riwayat bencana banjir yang telah lama terjadi, menjadikan masyarakat terbiasa melakukan berbagai tindakan untuk mengurangi risiko yang mereka alami seperti menyiapkan langkah - langkah dalam menghadapi bencana banjir, menyiapkan rencana aksi dalam menghadapi bencana banjir, melakukan pembagian peran anggota keluarga dan masyarakat, menyiapkan tempat evakuasi, dan menyiapkan berbagai perlengkapan gawat darurat.

Parameter kesiapsiagaan berikutnya adalah mobilisasi sumberdaya dan sistem peringatan bencana. Kedua parameter ini berada dalam kondisi hampir siap dan kurang siap, dengan nilai indeks masing - masing 
adalah 62,5 dan 47,5. Nilai indeks mobilisasi sumberdaya yang berada pada kategori hampir siap menjadi indikasi kurang atau rendahnya kapasitas kepala keluarga dalam menggerakkan sumberdaya mereka pada saat dan setelah banjir terjadi. Hal ini disebabkan kurangnya keterampilan mereka dalam hal pertolongan pertama, kesiapsiagaan, evakuasi korban dan pengolahan air bersih. Tindakan kesiapsiagaan yang dilakukan oleh warga bukan berasal dari pelatihan atau pemberitahuan dari pemerintah melainkan pengalaman mereka yang telah lama mengalami bencana banjir (Novian, 2018). Kalaupun ada pelatihan terkait, maka hanya diikuti oleh sebagian kecil warga saja. Keberadaan tabungan dan asuransi sebagai bagian dari sumberdaya keluarga juga belum, minat, akses ataupun informasi terkait keduanya yang masih terbatas untuk kalangan tertentu. Namun demikian, kebiasaan tolong menolong antar sesama keluarga sangat baik menjadi penutup celah kurangnya sumberdaya keluarga yang lain. Sebagian besar individu /rumah tangga mengaku mempunyai kerabat atau teman yang siap membantu apabila terjadi banjir. Hal ini akan mengurangi beban dan resiko terkait banjir yang yang kerap terjadi didaerah ini, namun tetap perlu didukung dengan upaya perbaikan terhadap faktor lain seperti sistem peringatan bencana.

Indikator kesiapsiagaan adalah bagaimana sistem peringatan dini yang ada di masyarakat, terutama di daerah yang memiliki kerentanan bencana banjir. Sistem peringatan meliputi tanda peringatan dan distribusi informasi jika terjadi bencana (Dodon, 2013). Sistem peringatan bencana yang kurang siap menggambarkan rendahnya pengetahuan dan ketersediaan teknologi terkini yang terkait dengan sistem ini. Gambaran mengenai sistem peringatan bencana di kelurahan Gunung Lingai menunjukkan bahwa penting untuk segera melakukan sosialisasi, fasilitasi, dan pelatihan oleh pemerintah mengenai sistem peringatan bencana, terutama pada masa sebelum banjir terjadi. Menurut Susanto (2006) dalam kondisi bencana, tidak mudah untuk menerapkan berbagai kebijakan yang terkait dengan kesiapsiagaan. Oleh sebab itu, pada kondisi aman perlu dilakukan berbagai upaya pencegahan, termasuk membangun dan mengembangkan sistem peringatan bencana non tradisional meskipun skala kecil di lingkungan tempat tinggal mereka.

\section{PENUTUP}

Berdasarkan hasil analisis dan pembahasan, secara umum dapat disimpulkan bahwa tingkat kesiapsiagaan rumah tangga di kelurahan Gunung Lingai Kecamatan Sungai Pinang kota Samarinda dalam mengantispasi bencana banjir sudah baik. Hal ini menunjukkan bahwa tingkat kesiapsiagaan rumah tangga dalam menghadapi banjir sebagian besar ditentukan oleh pengetahuan dan sikap mereka terkait dengan bencana alam tersebut. Indeks gabungan dari empat parameter mencapai 65,7. Angka ini dalam klasifikasi indeks kesiapsiagaan termasuk kategori siap. Namun demikian, komponen atau parameter mobilisasi sumberdaya dan sistem peringatan bencana harus mendapat perhatian serius dari semua stakeholder terutama pada saat pra bencana melalui ragam pendekatan. Diantaranya adalah pembaharuan berbagai kebijakan daerah terkait bencana alam, perbaikan akses, dan informasi terkait mobilisasi sumberdaya dan pemanfaatan teknologi informasi dalam kegiatan pengembangan sistem peringatan bencana. Selain itu, perlu pengintegrasian kesiapsiagaan bencana ke dalam kurikulum pendidikan formal, mulai dari tingkat pendidikan dasar, menengah hingga perguruan tinggi sebagai upaya untuk menciptakan generasi melek bencana (disaster literacy).

\section{DAFTAR PUSTAKA}

[1] Arikunto, Suharsimi (2010). Prosedur Penelitian Suatu Pendekatan Praktek. Jakarta. Rineka Cipta.

[2] Aryono, D.P. (2011). The Silent Disaster Bencana dan Korban Massal. CV. Sagung Seto. Jakarta.

[3] Badan Nasional Penanggulangan Bencana (2012). Peraturan Kepala BNPB No.02 Tahun 2012 Tentang Pedoman Umum Pengkajian Risiko Bencana. Jakarta.

[4] Badan Penanggulangan Bencana Daerah Kota Samarinda (2012). Peta Kawasan Rawan Bencana Banjir Dan Tanah Longsor Kota Samarinda.

[5] Bakornas PB (2007). Pengenalan Karakteristik Bencana dan Upaya Mitigasinya di Indonesia. Jakarta : 
Badan Nasional Penanggulangan Bencana., Halaman 15-24, Mei 2017.

[6] Devi Erlia (2017), Kesiapsiagaan Masyarakat dan Pemerintah Menghadapi Bencana Banjir di Kecamatan Martapura Barat Kabupaten Banjar. Jurnal Pendidikan Geografi, Vol.4 No.03.

[7] Dodon (2013). Indikator dan Perilaku Kesiapsiagaan Masyarakat di Permukiman Padat Penduduk Dalam Antisipasi Berbagai Fase Bencana Banjir. Jurnal Perencanaan Wilayah dan Kota Vol. 21 No. 2. Agustus 2013.

[8] Fatiya Rosyida, Khofifatu Rohmah Adi, Studi Eksplorasi Pengetahuan dan Sikap terhadap Kesiapsiagaan Bencana Banjir di SD Pilanggede Kecamatan Balen Kabupaten Bojonegoro. Jurnal Teori dan Praksis Pembelajaran IPS, Vol.2 No.1 April 2017, P ISSN 2503 - 1201, E ISSN $2503-5347$.

[9] Firmansyah., Iman. (2014). Hubungan Pengetahuan dengan Perilaku Kesiapsiagaan dalam Menghadapi Bencana Banjir dan Longsor pada Remaja Usia 15-18 tahun di SMA Al-Hasan Kemiri Kecamatan Panti Kabupaten Jember. Artikel ilmiah Hasil Penelitian Mahasiswa 2014.

[10] Ibnu Murbawan, Amar Ma'ruf, Abdul Manan, Kesiapsiagaan Rumah Tangga Dalam Mengantisipasi Bencana Banjir di Daerah Aliran Sungai (DAS) Wanggu (Studi Bencana Banjir di Kelurahan LepoLepo Kota Kendari), Ecogreen Vol. 3 No.2, Halaman 59-69 ISSN 24079049, Oktober 2017.

[11] Indawati, Lilik (2015). Analisis Tingkat Kerwanan Banjir dan Persepsi Masyarakat terhadap Upaya Pengurangan Dampak Banjir di Kecamatan Baureno Kabupaten Bojonegoro. Tesis. Surakarta : Universitas Sebelas Maret Surakarta.

[12] Jakaria,Y (2015). Mengolah Data Penelitian Kuantitatif Dengan SPSS. Bandung. CV. Alfabeta.

[13] LIPI - UNESCO (2006). Kajian Kesiapsiagaan Masyarakat dalam mengantisipasi Bencana Gempa
Bumi dan Tsunami, Deputi Ilmu Pengetahuan Kebumian Lembaga lmu Pengetahuan Indonesia, Jakarta.

[14] Notoatmodjo, S (2005). Promosi Kesehataan : Teori dan Aplikasinya. Jakarta : Rineka Cipta.

[15] Novian Andri Akhirianto (2018), Pengetahuan dan Kesiapsiagaan Masyarakat Terhadap Bencana Banjir di Kota Bekasi (Studi Kasus : Perumahan Pondok Gede Permai), Jurnal Alami (e-ISSN : 2548-8635), Vol.2, No.1, Tahun 2018.

[16] Sagala, S., Dodon., Wimbardana (2014). Adaptasi Non Struktural Penduduk Penghuni Permukiman Padat Terhadap Bencana Banjir Kabupaten Bandung. Jurnal Nasional Teknik Sipil.

[17] Sugiyono (2013). Metode Penelitian Kuantitatif, Kualitatif dan R\&D. Bandung. CV. Alfabeta.

[18] Sudjana (2015). Metode Statistika. Bandung. CV. Tarsito.

[19] Susanto, A. B (2006). Disaster Management di Negara Rawan Bencana : Sebuah Pendekatan Strategic Management. Jakarta. The Jakarta Consulting Group.

[20] Undang-undang N0.24 Tahun 2007 tentang Penanggulangan Bencana, Jakarta. 